\title{
'n Postliberale venster op die preek
}

I Nell

(UP)

\section{ABSTRACT}

\section{A Postliberal view on the sermon}

Over the same period that homiletics has enjoyed a resurgence, mainline Protestant churches have been in decline. The multiplication of preaching theories and resources has taken place alongside a growing concern about the life and future of the church. Despite alle the theories and resources many local pastors know something is lacking in their preaching. They've tried inductive preaching, story preaching, dialogue sermons, and homiletical plots. While these new methods have been exciting for the moment, many preachers sense something is still missing. It will be argued that it is partly due to the absence of thorough theological reflection. Theological reflection about preaching must also include an examination of the theological presuppositions implicit in contemporary homiletical theory and practice, as well as the development of richer theological alternatives. The postliberal, culture-linguistic theology of the "Yale School" has been one of the most important theological developments in the United States during the latter Twentieth century. The research will examine the postliberal theology as an alternative for contemporary homiletical theory and practice.

\section{INLEIDING}

\section{1 'n Probleem in die prediking}

In 'n tyd waar die invloed van die hoofstroom Protestantse kerke besig is om af te neem en daar groeiende bekommernis bestaan oor die toekoms van dié kerke, is dit belangrik om indringend te kyk na wat in die sentrum van dié tradisie gebeur ${ }^{1}$. In die sentrale gebeure van die Gereformeerde erediens speel die preek weer 'n sleutelrol en dit is in dié verband wat baie predikers besef daar skort iets in hul prediking. Baie het begin om gebruik te maak van nuwe preekvorme soos induktiewe prediking, verhalende prediking, dialogiese preke en selfs ' $n$ homiletiese plot. Ten spyte van die opwinding wat laasgenoemde tot gevolg gehad het, is die gevoel steeds dat alles nie pluis is nie. Dit het te make met die feit dat prediking by uitstek 'n teologiese onderneming is en daar voortdurend aandag gegee moet word 
aan die teologiese analise van die preekgebeure ${ }^{2}$. Nog belangriker as die teologiese inhoud van die prediking is die vraag na die teologiese vertrekpunte waarmee gewerk word.

Wat laasgenoemde betref, is daar verskeie homiletici wat binne die Suid-Afrikaanse konteks moeite doen met die ontwikkeling van preekteorieë wat belangrike teologiese perspektiewe ondersoek ${ }^{3}$. In hul publikasies ontwikkel hulle dan ook met vrug die implikasies van verskillende teologiese benaderings. ' $n$ Resente benadering waarvan myns insiens nog nie genoegsaam in die Suid-Afrikaanse homiletiese konteks kennis geneem is nie, is die sogenaamde postliberale (ook bekend as die postkritiese of kultuur-linguistiese) teologie wat gekoppel is aan die Yale Divinity School in die V S A.

\subsection{Doel van studie}

Die doel van die studie is om by hierdie, myns insiens aanvullende, benadering te gaan kers opsteek in die ontwikkeling van 'n teologiese preekteorie. Dit word gedoen met die hoop dat die postliberale tradisie 'n alternatiewe venster kan open in die teologiese analise van die preekgebeure en moontlik ook groter helderheid kan bring wat betref die teologiese vertrekpunte waarmee gewerk word. Die postliberale of kultuurlinguistiese teologiese denkrigting word beskou as een van die belangrikste teologiese ontwikkelinge in die V S A gedurende die laaste deel van die twintigste eeu.

In die studie sal aan die volgende aandag gegee word: Die historiese wortels van die postliberale teologie. Hooftrekke van die postliberale teologie. Die uitgangspunte van 'n postliberale hermeneutiek. 'n Bespreking van die homiletiese implikasies wat laasgenoemde inhou. Kritiek teen die postliberale tradisie en enkele gevolgtrekkings.

\section{HISTORIESE WORTELS}

\subsection{Yale Divinity School}

Postliberalisme word normaalweg geassosieer met die Yale Divinity School. Dit was veral die publikasie van George Lindbeck se The Nature of Doctrine (1984) wat impetus aan hierdie benadering verleen het met sy uitdaging aan die liberale en revisionistiese tradisies 4 . In die laaste hoofstuk van sy boek praat hy van 'n "postliberale teologie". Die term "narratiewe teologie" word ook aan dié rigting gekoppel, alhoewel die denkers in hierdie tradisie nie altyd daarvan hou om so "geklassifiseer" te word nie.

Onder punte 3 en 4 hieronder sal meer breedvoerig aandag geskenk word aan die ontwikkeling van die postliberale denke. Daar kan op hierdie 
stadium net kortliks genoem word dat postliberale teoloë soos Lindbeck en Frei 'n "kognitief-proposisionele" benadering tot die teologie as premodern verwerp. Hulle is verder van oordeel dat liberale "ervarings-ekspressiewe" teorieë weer in gebreke bly om werklik rekening te hou met beide die mens se verskeidenheid van ervarings en die bemiddelende rol wat kultuur speel in denke en ervaring. Daarom word 'n "kultuur-linguistiese" benadering ontwikkel waarin die belangrikste komponente van die postliberalisme vervat iss.

\subsection{Verskillende invloede en milieu}

'n Verskeidenheid van invloede lê agter hierdie teologiese benadering: die teologie van Karl Barth, nuwe maniere waarop Thomas van Aquino gelees is, Thomas Kuhn se wetenskapsfilosofie, analitiese filosowe soos Wittgenstein en Gilbert Ryle, sosioloë soos Peter Berger, antropoloë soos Cliffort Geertz, en literêre teoretici soos Erich Auerbach. Meeste van die denkers wat as "postliberales" beskou word, het of by Yale klas gegee of daar gestudeer, met die bekende teoloog van Yale, H Richard Niebuhr, wie se denke die grondslag van baie van die postliberale temas vorm ${ }^{6}$.

Dit is belangrik om die milieu te verstaan waarbinne laasgenoemde 'n invloed uitgeoefen het. By baie van die godsdiens departemente in die VSA is godsdiens bestudeer as 'n universele fenomeen. Temas en simbole is beskou as manifestasies van sakrale ervarings op verskillende maar tog verwante maniere in die onderskeie tradisies. So gesien is die Christelike teologie een stel antwoorde op universele menslike vrae. Hierdie beskouing is ook bekend as 'n liberale of revisionistiese manier van dink oor die teologie soos wat Paul Tillich op klassieke manier geformuleer het. By Yale was dit anders, aangesien die klem geval het op die bestudering van spesifieke godsdienstige tradisies, elk in sy historiese en kulturele konteks. Studente het dus die Christendom of Judaïsme of Boeddhisme bestudeer, maar nie as "godsdiens of religie" nie?

\subsection{Konteks van nadenke}

Dit was hierdie milieu wat ' $n$ besondere konteks van nadenke geskep het en deur die volgende gekenmerk is8: Eerstens 'n groeiende skeptisisme oor die aanneemlikheid van 'n liberale lewensbeskouing en die wyse waarop oor godsdiens nagedink is. Die klem het baie sterk begin val op die uniekheid van individuele godsdienstige tradisies. Tweedens 'n narratiewe benadering tot die teologie. Dit beteken dat daar baie aandag geskenk is aan die vorm van die Bybelteks (literêre genre) soos wat dit in die Bybel voorkom. Daar is veral gekyk na die narratiewe struktuur deur die gebruik 
van analoë tegnieke uit die literère kritiek. Derdens die gebruik van sosiale teorieë waarin die belang van kultuur en taal in die skep en interpretasie van denke en ervaring ' $n$ rol speel. In aansluiting by filosowe soos Alisdair MacIntyre, verwerp die postliberaliste die appêl van die Verligting op "universele rasionaliteit" en die liberale uitgangspunt van onmiddellike religieuse ervarings wat gemeenskaplik is aan die mensdom. Postliberalisme argumenteer dat alle denke en ervaring histories en sosiaal bemiddel word, en baseer hulle teologiese program op 'n terugkeer na religieuse tradisies wie se waardes van binne toegepas word. Vierdens, en in aansluiting by laasgenoemde, die kritiese ondersoek na die verhouding tussen Bybeltekste en die gemeenskappe wat dit lees - met ander woorde hoedat hierdie narratiewe die identiteit van gemeenskappe, hulle lede, en hulle verstaan van die God wat hulle aanbid, help vorm.

\section{POSTLIBERALE TEOLOGIE}

Die belangrikste sistematiese teoloë wat deel vorm van die postliberale skool en wat almal op een of ander stadium aan Yale verbonde was, is Hans Frei, George Lindbeck en Ronald Thiemann. Hans Frei, aan wie die postliberale teologie dalk die grootste dank verskuldig is, se twee bekendste publikasies is The Eclipse of Biblical Narrative (1974) en The Identity of Jesus (1975). Soos reeds genoem is George Lindbeck se bekendste werk The Nature of Doctrine in a Postliberal Age (1984). Een van Ronald Thieman se bekendste werke is weer Revelation and Theology: The Gospel as Narrated Promise (1985). Op die gebied van die Christelike etiek is daar onder andere Stanley Hauerwas wat 'n groot bydrae gelewer het in die ontginning van 'n postliberale benadering tot dié veld met onder andere die volgende publikasies: A Community of Character (1981) en The Peacable Kingdom (1983).

Dit is nie moontlik om elkeen se werk hier te bespreek nie. Die postliberale teologie het wel die volgende gemeenskaplike kenmerke" Eerstens is postliberale teologie "non-foundationalist" of "antifoundational". Dit beteken dat hulle die opvatting van 'n universele fundering van kennis verwerp. Hulle glo dus dat ervaring altyd geïnterpreteerde ervaring is, gevorm deur taal en vorige ervarings. Tweedens raak postliberale teologie nie betrokke by sistematiese apologetiek nie. Postliberale teoloë maak ad hoc aansluitings by die filosofie, of kuns of kultuurervarings van die dag. Hulle glo nie dat enige nie-christelike raamwerk, filosofies of kultureel, die konteks kan voorsien waarbinne Christelike aansprake verdedig moet word nie. Derdens, in aansluiting by 
genoemde twee punte, neem die postliberale teologie dus 'n posisie in teenoor "revisionistiese" benaderings tot die teologie. Dié benaderings vind hul wortels in die liberale tradisie van Schleiermacher en word gewoonlik geassosieer met die Universiteit van Chicago. Vierdens plaas postliberale teologie 'n groot premie op die gemeenskap en is dus "communitarian", wat beteken dat daar 'n groot appèl gemaak word op die waardes, ervarings en taal van 'n gemeenskap, eerder as op die van die individu. Vyfdens beklemtoon postliberale teologie historisiteit deur aandag te skenk aan die verskille tussen godsdienste, eerder as om te fokus op die dinge wat hulle in gemeen het of om te argumenteer dat hulle almal eintlik dieselfde dinge sê.

Ter illustrasie van laasgenoemde kan ons kortliks na die werk van Hans Frei kyk ${ }^{10}$. Dit kan help om groter duidelikheid te kry oor die doel, metode en inhoud van die postliberale teologie. Campbell som sy werk soos volg op: "Frei's theology may be described, in direct opposition to liberal theology, as having a dogmatic aim, an Anselmian method, and a Christological content"11. Wat beteken dit?

Vir Frei het die teologie 'n dogmatiese eerder as 'n apologetiese doel. Die doel van teologie is dan die tweede orde beskrywing van die logika en inhoud van die Christelike geloof, soos wat dit beliggaam is in die eerste orde taal en praktyke van die Christelike gemeenskap. Apologetiek poog om geloof te verduidelik in terme van een of ander sisteem wat buite die teologie funksioneer. Die doel van teologie, in onderskeiding van apologetiek, is Christelike selfbeskrywing. Dit beteken dat teologie "godsdiens spesifiek" is, 'n interne aktiwiteit van die Christelike gemeenskap en nie ondergeskik aan algemene teorieë van betekenis of betekenisvolheid. In dié verband sluit Frei in sy latere werke dan ook by Lindbeck aan ${ }^{12}$.

Frei, net soos Barth, werk met 'n Anselmiaanse metode van "faith seeking understanding". Geloof wat op soek is na verstaan, is nie 'n innerlike ervaring of ' $n$ unieke manier van ken nie. Geloof wat gegrond is in aanbidding en dissipelskap, is die aanvaarding van die Credo van die geloofsgemeenskap en bestaan dus uit die aanleer van die taal van die gemeenskap. Laasgenoemde onderstreep die linguistiese karakter van dié metode $^{13}$.

Frei se teologie, soos wat mens kon verwag, het 'n Christologiese inhoud. Die eiesoortigheid van dié Christologiese inhoud is vir hom, in aansluiting by veral $\mathrm{H}$ Richard Niebuhr, geleë in die onvervangbare Identiteit van Jesus Christus. "For Frei the starting point is not human experience or existence, but rather the specific, unsubstitutable identity of 
Jesus Christ, which is rendered in the interplay of character and incident in the gospel narratives" ${ }^{14}$. Dit beteken onder andere dat die soteriologie 'n funksie is van die Christologie, en nie andersom, soos wat in die liberale teologie die geval is nie.

'n Teologiese benadering het volgens Placher dikwels die wydste impak in die wyse waarop die "klassieke" tekste in diskussies terug gebring word en die foute waarteen daar gewaarsku word ${ }^{15}$. Dit is in dié verband wat veral Frei die teologie van Karl Barth weer in die kontemporêre teologiese diskussie ingevoer het. Daarom som Placher die postliberale teologiese tradisie soos volg op: "Out of Hans Frei's studies of history of modern hermeneutics and of Karl Barth in particular, and George Lindbeck's reflections on ecumenical theology in the light of new readings of Aquinas and new styles of sociology and anthropology, postliberal theology emerged" 16 .

Twee van die resente homilete wat die postliberale tradisie vir die homiletiek toeganklik maak, is Charles Campbell en Richard Eslinger. In sy boek Preaching Jesus: New Directions for Homiletics in Hans Frei's Postliberal Theology (1997) ondersoek Charles Campbell die postliberale teologie van Hans Frei, terwyl Richard Eslinger in Narrative and Imagination (1995) veral aandag skenk aan narratiewe hermeneutiek en teorieë oor verbeelding. Die fokus verskuif nou na die bespreking van 'n postliberale hermeneutiek.

\section{POSTLIBERALE HERMENEUTIEK}

\subsection{Verskillende modelle}

In die hermeneutiek word gewoonlik gepoog om 'n antwoord te vind op die vraag: Watter raamwerk word gebruik vir die interpretasie van die teks, self en die wêreld? Volgens Lindbeck is daar veral twee dominante alternatiewe wat as antwoord op hierdie vraag aangebied word ${ }^{17}$. Die eerste is 'n "kognitief-proposisionele model", terwyl die tweede 'n "ervarings-ekspressiewe" een is.

Die kognitief-proposisionele benadering se ideologiese wortels vind ons in die Verligting. In hierdie benadering val die klem op "the ways in which church doctrines function as informative propositions or truth claims about objective reality". Die alternatief tot laasgenoemde, die ervaringsekspressiewe model, fokus weer op die mens se "noninformative and nondiscursive symbols of inner feelings, attitudes, and existential orientations"18. Laasgenoemde se ideologiese wortels word gevind in die Romantiek se reaksie op die "Era van die Rede" en in die teologiese 
program van Friedrich Schleiermacher. Soos wat met die kognitiewe model die geval is, word die betekenis van die Skrif buite die teks gesoek in een of ander nie-proposisionele konteks. In die sentrum van die hermeneutiek van hierdie model is die oortuiging dat daar een of ander "shared interior experience" bestaan wat normatief, uniek en onherleibaar is ${ }^{19}$.

'n Kenmerk van beide hierdie modelle is dat daar nie erns gemaak word met die literêre genre van die Bybeltekste en in die besonder die "Bybelse narratief" nie ${ }^{20}$. By die kognitiewe model is die betekenis van dié narratief gesoek in die idees waarna dit verwys. Sodra hierdie idee of punt in die narratief ontdek is, was die narratiewe vorm van geen verdere belang nie. In die ervarings-ekspressiewe model is dié narratief weer beskou as 'n deposito van waarhede of as 'n voorbeeld van kontemporêre menslike ervaring. Placher skryf dat dié benadering die Bybelse narratief behandel het as: "examples or lessons or illustrations of general principles, whose meaning does not lie in their narrative structure" 21 . Dit was hierdie soort hantering van die Bybelse verhale wat Hans Frei gelei het tot die titel van sy bekende boek: "The Eclipse of Biblical Narrative" (1974) waarin hy dié probleem deeglik ondersoek.

\section{2 'n Kultuur-linguistiese model}

Dit was ook in dié verband wat Lindbeck en Frei 'n grondige skuif in die hermeneutiese taak ingelei het, en wat later as postliberale teologie bekend sou staan.

Lindbeck se bydrae begin by die manier waarop hy reken kerklike leerstellings of dogmas funksioneer: "The function of church doctrines that becomes most prominent in this perspective is their use, not as expressive symbols or as truth claims, but as communally authorative rules of discourse, attitude and action"22. Dit is wat hy dan 'n kultuur-linguistiese benadering noem, en "the implied view of church doctrine will be referred to as a 'regulative' or 'rule' theory". Lindbeck beskou dan 'n geloofsgemeenskap as analoog aan 'n kultuur of 'n taal: "Like a culture or language, it is a communal phenomenon that shapes the subjectivities of individuals rather than being primarly a manifestation of those subjectivities"23. Kortom, ons geloofsgemeenskap vorm ons deurdat ons gebore word in 'n tradisie van stories, rituele, en aksies wat beteken dat ons godsdienstige ervarings onvermydelik 'n "Christelike ervaring" is.

Selfs nog voor die publikasie van Lindbeck se The Nature of Doctrine, het Hans Frei reeds sy eie beweging in die kultuur-linguistiese rigting aangedui in lesings wat hy by Harverford College gegee het. Gedurende die laaste jare van Frei se lewe het hierdie benadering dan ook 
vir hom al hoe belangriker geword ${ }^{24}$. In sy eerste belangrike publikasie The Eclipse of Biblical Narrative (1974) was hy alreeds besig met die grondwerk vir die latere verskuiwings. Frei was van oordeel dat Christelike teoloë sedert die begin van die sewentiende eeu die Bybel verkeerd gelees het. Voor daardie tyd het Christene volgens hom die Bybelse narratiewe verstaan as 'n defmiëring van die werklike wêreld. Die wêreld is 'n plek wat deur God geskep is, waar die Here vir Israel uit slawerny bevry het, waar Christus gekom het en die kerk ontstaan het en Christus weer sal kom. Christene vind die sin van hulle lewens deur hulself binne hierdie verhaal te plaas. Maar sedert die sewentiende en agtiende eeu: "It is no exaggeration to say that all across the theological spectrum the great reversal had taken place; interpretation was a matter of fitting the biblical story into another world with another story rather than incorporating that world into the biblical story" 25 .

Die kultuur-linguistiese benadering ontken dus dat daar een of ander universele nie-bemiddelde religieuse ervaring bestaan, los van menslike taal en kultuur. Dit beklemtoon dat die hart van godsdiens geleë is in die lewe binne 'n spesifieke historiese godsdienstige tradisie, waarvan die idees en waardes geinternaliseer word en waarvan die narratief ' $n$ baie geskikte middel van oordrag is ${ }^{26}$. Placher som dit goed op: "Language creates the possiblility of religious experience, indeed of any fully human experience. Therefore different religions do not represent different expressions of the same experience" 27 .

Hierdie sogenaamde grammatika van die Christelike geloof kom op sy beste tot uitdrukking in die konteks van aanbidding, waar die Skrifverhale gelees, gesing en verkondig word en waar die verhale nuut "ervaar" word deur die deelname aan die sakramente ${ }^{28}$. Die voorveronderstelling waarmee 'n kultuur-linguistiese hermeneutiek dus werk, is dat geloofservaring gevorm word deur 'n formatiewe omgewing van kultuur en taal. Vir die kerk kom hierdie kultuur en taal dan tot volle uitdrukking waar die Bybelse narratiewe vorm gee aan haar aanbidding, riglyne bied vir die prediking en beleef en uitgeleef word in die sakramente ${ }^{29}$.

\subsection{Die belang van Bybelse narratiewe}

Hierbo is verwys na die "great reversal" waarvan Frei melding maak. Dit beteken dat gelowiges begin het om hul eie wêreld van ervaring as vertrekpunt te neem, terwyl baie teoloë gereken het dat die realiteite van die Bybelse wêreld in die mense se ervaringswêreld ingepas moes word. Dit het volgens hom op een van twee maniere plaasgevind: Of die betekenis van die verhale is gevind in hulle oënskynlike verwysing of 
onvermoë om te verwys na sekere historiese gebeure. Historiese navorsing begin gewoonlik by die mens se ervaring en beweeg dan terug in die verlede. Dit beteken dat die Bybelse verhale, soos enige ander antieke tekste, "waar" is, indien die gebeure wat hulle beskryf binne hierdie historiese raamwerk kan inpas. Of die betekenis van die verhale is nie gesoek in die verhaal as sodanig nie, maar in die morele les of godsdienstige waarheid wat dit illustreer ${ }^{30}$. Die eerste opsie poog dus om ' $n$ historiese kern in die verhaal te vind, terwyl die tweede opsie op soek is na morele lesse in die verhaal. In beide gevalle gaan die verhaal as sodanig verlore. Hierdie verlies is onvermydelik wanneer die teologie 'n sistematies apologetiese strategie aanvaar, waarin een of ander eksterne definisie aan die Christendom die spelreëls bepaal en daar gepoog word om die Bybels narratiewe op daardie gronde te verdedigi1 .

Nie een van hierdie alternatiewe bied volgens Frei 'n getroue interpretasie van die Bybelse narratiewe nie. Soos wat die geval is met "realistiese narratiewe", bedoel die Bybelse narratiewe wat hulle sê. Hulle betekenis word gevind in die interaksie van karakter en die gebeure wat vertel word. Sy hermeneutiese voorstel onderstreep dit: "a realistic or history-like (though not necessarily historical) element is a feature, as obvious as it is important, of many of the biblical narratives that went into the making of Christian belief" 32 .

Die punt wat Frei dus maak, is dat die betekenis van baie Bybelse narratiewe ten nouste gekoppel is aan hulle "realistiese karakter" en in die besonder aan die spesifieke narratiewe vorm (narrative rendering or depictive shape) van die gebeure wat vertel word. Hulle betekenis is dus ' $n$ funksie van hulle narratiewe uitbeelding. Dit beteken verder dat die ignorering van hulle spesifieke narratiewe vorm gelykstaande is aan die verlies van hulle betekenis. Samevattend beteken realistiese narratiewe vir Frei dus drie dinge: eerstens die "inseparability of subject matter from its depiction or cumulative rendering", tweedens die "literal rather than symbolic quality of the human subject and his historical context" en derdens die "mutual rendering of character, circumstance, and their interrelation" 33 .

Uit laasgenoemde blyk die voorrang wat die Bybelse narratiewe geniet binne 'n kultuur-linguistiese konteks bo die geloofservaring van die individu. Die belang van Bybelse narratiewe en die klem wat binne die kultuur-linguistiese benadering daarop geplaas word, berus egter op sekere voorveronderstellings waarvan die volgende die belangrikste is ${ }^{34}$ : 


\subsubsection{Die voorrang van 'n narratiewe wyse van Skrifinterpretasie}

Die klem wat geplaas word op die belang van 'n narratiewe wyse van Skrifinterpretasie is die vrug van verskeie literêre studies wat gedoen is oor die Bybelse narratiewe. Hierdie studies het tot die gevolgtrekking gelei dat die narratief sentraal staan in die wyse waarop die Bybel kommunikeer ${ }^{35}$. Die primaat van die narratiewe wyse van Skrifinterpretasie is volgens Eslinger ook van toepassing op die "nie-narratiewe" gedeeltes in die Skrif soos die reinheidsvoorskrifte in Deuteronomium, Psalms, ander wysheidsliteratuur, die Pauliniese corpus en die apokaliptiese literatuur ${ }^{36}$. Daar is gevind dat alhoewel die vorm nie in die genre van die narratief is nie, dié literatuur wel deel vorm van die groter Bybelse storie. Die kanoniese proses verbind hierdie gedeeltes dus aan die groter Bybelse narratiewe. Thieman vat dit goed saam: "narrative highlights both a predominant literary category within the Bible and an appropriate theological category for interpreting the canon as a whole" ${ }^{37}$.

\subsubsection{Die voorrang van die Bybelse narratiewe wêreld}

Dit is volgens Eslinger een ding om te argumenteer vir 'n narratiewe wyse van Skrifinterpretasie, maar dit is 'n ander aanspraak vir die primaat van 'n Bybelse wêreld bo ander sosiale en kulturele wêrelde. By implikasie beteken dit dat dié ander wêrelde fiktief of foutief kan wees ${ }^{38}$. In 'n tyd van inklusiwiteit en pluralisme kan so 'n standpunt dalk vreemd op die oor klink, maar die belang van die Christelike geloof se partikulariteit en waarheid vorm deel van dié tradisie. Thieman skryf in verband met die hervormers en hul navolgers: "scripture depicts a real world, temporally structured, which encompasses both the times and stories of the text and those of the reader... since the world depicted by the Bible is the only real word, the reader must fit his or her own experience into scripture's cumulative narrative, thus becoming a 'figure' of the text" ${ }^{39}$.

\subsubsection{Die voorrang van 'n ekklesiale konteks vir narratiewe interpretasie}

Die twee sake wat so pas bespreek is, kan maklik die indruk wek dat dit nou ten diepste gaan oor die "narratiewe kwaliteit" van alle menslike bestaan. Wat ons daarvan weerhou om so 'n gevolgtrekking te maak is volgens Eslinger die aandrang op die primaat van 'n ekklesiale konteks vir die interpretasie van die Skrif ${ }^{40}$. Die Bybel self het volgens Brueggemann 'n "vested interest" in die vorming van 'n geloofsgemeenskap ${ }^{41}$. Volgens Hauerwas is die Bybel se storie daarom nie maar net selfverwysend nie "but rather creates a people capable of being the continuation of the 
narrative by witnessing to the world that all creation is ordered to God's good end. The church is the necessary context for the testing of the narrative" ${ }^{42}$. Die kerk van Jesus Christus het dus 'n primaat wat betref die hermeneutiese konteks vir die Skrif.

\section{HOMILETIESE IMPLIKASIES}

Die kursoriese bespreking van die postliberale teologie en hermeneutiek het reeds rigtingwysers voorsien wanneer daar nou verder besin word oor die homiletiese implikasies van dié benadering. Die homiletiese implikasies wat nou bespreek word, is myns insiens ook die bydrae wat 'n postliberale homiletiek bied om 'n alternatiewe venster op die preek en die liturgie te open.

\subsection{Vraagtekens oor narratiewe prediking}

'n Kenmerk van die homiletiese navorsing gedurende die afgelope drie dekades was die wyse waarop daar, in aansluiting by die nuwe waardering wat daar vir die narratief ontwikkel het, inderdaad moeite gedoen is met die ondersoek na die verhouding tussen narratief en prediking. Van die belangrikste bydraes, in wat bekend geword het as narratiewe prediking, vind ons onder andere in die werke van Rice ${ }^{43}$, Craddock ${ }^{44}$ en Lowry ${ }^{45}$. Elkeen van hulle het uit die aard van die saak 'n eie verstaan gehad van die betekenis van die narratief vir die prediking. Ten spyte van verskille, het hulle volgens Campbell wel die volgende in gemeen ${ }^{46}$ : Hulle is in reaksie teen kognitief-proposisionele prediking en ken gevolglik 'n sentrale plek toe aan menslike ervaring in die prediking met die klem op die ervaringsgebeure wat deur die preek bewerk word. Hulle worstel om twee verskillende storie-wêrelde (die Bybelse wêreld en die kontemporêre wêreld) met mekaar te verbind. Hulle bied 'n formele verstaan van die rol van narratief in die prediking met besondere klem op die belang van gelykenisse en die ontwikkeling van 'n plot.

Narratiewe homiletiek het dan ook volgens Campbell 'n belangrike bydrae gelewer tot die prediking. Die volgende is die belangrikste ${ }^{47}$ : Eerstens het die klem op die narratief weer die fokus op die Skrif en die teks laat val. Tweedens het narratiewe prediking die vormgewing van die preek geweldig verryk. Die deduktiewe drie-punt preek is vervang deur 'n verskeidenheid van nuwe vorme. Derdens het narratiewe homiletiek 'n nuwe waardering gebring vir die indikatiewe karakter van die evangelie. Vierdens is die holistiese karakter, wat nie net die intellek aanspreek nie maar ook die emosies raak, herwin. Laastens het narratiewe prediking die 
poëtiese en metaforiese dimensies van die taal van die prediking belig en die rol van verbeelding in die prediking herontdek.

Ten spyte van hierdie positiewe bydrae, is dit volgens Campbell ' $n$ vraag of dit gelei het tot 'n meer lewendige en geloofwaardige kerk. Volgens hom het die hoofstroom kerke gedurende die tyd wat narratiewe prediking 'n bloeityd beleef het, 'n afname getoon. Voorts was daar 'n ernstige gebrek aan teologiese refleksie, daar was ook nie 'n noukeurige ondersoek na die teologiese en hermeneutiese voorveronderstellings onderliggend aan narratiewe prediking nie ${ }^{48}$.

Die belangrikste punt van kritiek wat Campbell teen narratiewe prediking inbring, is dat alhoewel daar weggestuur word van kognitiefproposisionele prediking, dit vasval in die ervarings-ekspressiewe benadering wat hierbo bespreek is. Die narratief word gevolglik waardeer vir die vermoë wat dit besit om ervaring in die preek te bewerk. Die verstaan van prediking en die liturgie bloot as 'n "ervaringsgebeure" het dus ' $n$ ander oriëntasie as wat in 'n kultuur-linguistiese model voorgestel word. Hierdie klem op "ervaring" in narratiewe prediking het verder ook 'n oorbeklemtoning van die individualistiese verstaan van prediking tot gevolg. Volgens Campbell het narratiewe prediking dus nog nie die "postliberale" skuif gemaak na 'n kultuur-linguistiese benadering tot die prediking nie, omdat dit bly funksioneer binne 'n moderne, liberale raamwerk ${ }^{49}$.

Dit is in dié verband wat die postliberale teologie en hermeneutiek ' $n$ ander venster bied waardeur 'n postliberale homiletiek kan kyk in die soeke na die oplossing vir genoemde probleme. Nuwe perspektiewe wat daardeur ontwikkel, word vervolgens bespreek.

\subsection{Die narratief as venster op die karakter van God}

Vir 'n postliberale homiletiek is die belangrikste funksie van die Bybelse narratief geleë in die feit dat dit vir ons 'n venster open op die unieke karakter van God. In die Bybelse verhale vind ons 'n beskrywing van die karakter van God "not by telling what God is in and of himself, but by accounts of the interaction of his deeds and purposes, with those of creatures in their everchanging circumstances" $\$ 0$. Wat dan opvallend is in die Skrifverhale is die wyse waarop God misterieus en verborge bly, alhoewel sy werksaamheid deurgaans as veronderstelling funksioneer.

Volgens Campbell was die funksie van die evangelie-verhale vir beide Frei en Barth dan ook die unieke, onvervangbare identiteit van Jesus deur die interspel van karakter en gebeure. Dit gaan dus nie oor narratiewe strukture in die algemeen nie, of oor enige ander verhale as sodanig nie, 
maar oor die spesifieke evangeliese verhale wat die identiteit van Jesus Christus beskryf. In ' $n$ postliberale homiletiek is die narratief daarom belangrik, nie omdat dit 'n "homiletiese plot" vir preke bied nie, en ook nie omdat dit storie-vertel in die prediking aanmoedig nie, maar omdat dit 'n voertuig is waardeur die evangelies die identiteit van Jesus van Nasaret kommunikeer ${ }^{51}$. Enkele van die homiletiese implikasies van laasgenoemde is onder andere:

* Wat die inhoud van die preek betref, verskuif die fokus van plot na karakter, en in die besonder dan na die sentrale karakter in die evangelies, naamlik Jesus van Nasaret ${ }^{52}$. Laasgenoemde het die verdere implikasie dat wanneer daar oor die karaktertrekke van Jesus gepreek word, dit nie geabstraheer kan word van sy unieke, onvervangbare optrede soos wat dit in die evangelies beskryf word nie. Jesus kan dus nie primêr "geïdentifiseer" word in terme van een of ander abstrakte kwaliteit soos byvoorbeeld die liefde wat op Hom toegepas word nie. 'n Postliberale homiletiek fokus ook nie op Jesus se innerlike lewe, sy bewussyn of selfverstaan nie, maar op die openbare uitvoering van sy sending 53 .

Wat die vormgewing van die preek betref, is die gebruik van 'n spesifieke preekvorm in 'n postliberale homiletiek nie werklik belangrik nie. Die logika van die Bybelse verhale kan ook in 'n nienarratiewe vorm aangebied word, maar altyd met die behoefte om weer na die Bybelse storie terug te keer. Dit beteken dat gewaak moet word teen 'n simplistiese beweging van 'n narratiewe teks na 'n narratiewe preek. Frei was baie bewus van die feit dat Christene nie 'n spesifieke genre aanbid nie, maar eerder die Een wie se identiteit deur die verhale vertel word. Daarom het hy in sy preke daarvan gehou om te werk met die klassieke beweging van eksegese na toepassing, eerder as die induktiewe beweging van menslike ervaring na die teks ${ }^{54}$. Frei se aansluiting by Barth, wat selfs nie van so iets soos 'n preekinleiding wou weet nie, blyk duidelik in dié verband.

Wat die preekhandeling (homiletiese uitvoering van die Skrif) betref, maak 'n postliberale homiletiek erns met die manier waarop die prediking 'n interpretatiewe uitvoering ("performance") is van die Skrif5s. Dit het belangrike implikasies waaronder die volgende: Die primêre taak van die prediker en die gemeente is nie om die preek te 
probeer modelleer op Jesus se preke, vertellings en gelykenisse nie, maar om eerder 'n dissipel te wees. Dissipels wat ook poog om in die preekpraktyk en in die gehoorsame antwoord daarop die vertelling van Jesus se verhaal na te volg. Jesus is dus nie die modelprediker nie, maar die identiteit van Jesus soos dit in die evangelieverhale vertel word, voorsien die patroon vir 'n lewe van dissipelskap vir die prediker en die geloofsgemeenskap. Prediking as dissipelskap gevorm deur die identiteit van Jesus Christus is dus nie in die eerste plek om 'n goeie storieverteller of 'n goeie hoorder te wees nie, maar eerder 'n daad van morele gehoorsaamheid - "Faithful preaching thus enacts on behalf of the entire church an interpretative performance of the story of Jesus" 56 .

*

In aansluiting by laasgenoemde beteken dit dat, wat die persoon van die prediker betref, daar veel meer ter sprake is as bloot hermeneutiese metode en homiletiese tegniek. In 'n postliberale benadering tot die homiletiek raak die karakter van die prediker, waaronder deugde, gewoontes en dissiplines, van groot belang57.

\subsection{Die belang van die ekklesiologiese konteks en die opbou van die} kerk

'n Kenmerk van die Bybelverhale is dat dit voortgesit word in die lewe van die geloofsgemeenskap. In dié sin open die narratiewe van die Skrif 'n wêreld waarin ons as gelowiges kan leef. Christene is dus mense wat leef binne dié eiesoortige wêreld wat deur die Bybelse verhale vertel word. En dié eiesoortigheid is geleë in die unieke karakter van die wêreld wat dit openbaar - 'n wêreld waarin buitestaanders opgesoek en met wie gemeenskap herstel word, waar sondaars vergewe word, waar genesing plaasvind en waar gasvryheid bewys en ontvang word. Dit is dus beide ' $n$ intratekstuele wêreld van interne verhoudings tussen verskillende Bybeltekste maar ook 'n ekklesiologiese wêreld waarin die lewe van die kerk hier en nou geïnkorporeer word in 'n lewe van dissipelskap. Wat laasgenoemde betref is daar volgens Eslinger ' $n$ dubbele beweging in die Christelike gemeenskap met betrekking tot die Bybelse narratiewe: "on one hand, a calling in the stories inviting Christians to become who they are; and on the other, a formative intending so that those Christian people may truly hear the Word"58. Laasgenoemde het weer die volgende implikasies:

* Wat die liturgie betref, is dit onder andere die oefenskool vir die Christelike deugde in die vorming van 'n "community of character". 
In dié verband word die krag van die gepredikte woord gevind in die wyse waarop dit help om mense te vorm wat die Skrifverhale reg hoor, verstaan en uitleef. Vanuit dié perspektief beteken dit verder dat die prediking ook die inoefening is van persoonlike en gemeenskaplike geheue ("memory") deur die voorlesing en verkondiging van die Woord ${ }^{59}$. In aansluiting en ter ondersteuning van laasgenoemde, is die gebruik van 'n leesrooster (soos byvoorbeeld die $\mathrm{RCL}$ ) ' $\mathrm{n}$ besondere waardevolle hulpmiddel. Daarom is dit ook verblydend om te sien dat al meer kerke van hierdie ekumeniese hulpmiddel begin gebruik maak.

* In aansluiting by die belang van die liturgie, plaas 'n postliberale benadering tot die preek ook besondere klem op die opbou van die gemeente. Vir Frei is die opbou van die kerk dié sentrale funksie van die prediking. Volgens Campbell word die verskil tussen 'n moderne en 'n postmoderne benadering tot die prediking veral hierin gevind. Prediking wat fokus op individuele ervaring met as primêre funksie die transformasie van die individu is kenmerkend van 'n moderne, liberale raamwerk. Binne 'n kultuur-linguistiese benadering gaan die gemeenskap die individu vooraf en bestaan die individu binne die konteks van verhoudings en rolle wat in 'n spesifieke gemeenskap gevind word. So 'n verstaan van prediking ignoreer nie die individu nie, maar sien sy/haar behoeftes binne die konteks van die geloofsgemeenskap. Die vertrekpunt is dat die grondliggende behoefte van mense is om gehoorsame dissipels te wees in 'n geloofwaardige gemeenskap. Dit beteken verder dat die gemeente as interpreterende gemeenskap, waar meer as net die individu aan die lees en verstaan van die Skrif deelneem, 'n belangrike rol speel in die verstaan van die Skriforo.

Liturgie en prediking wat die klem laat val op die belang van die Bybel se narratiewe wêreld kan nie sonder 'n pneumatologiese begronding nie - "For Frei the salvific meaningfulness of Jesus Christ becomes a contemporary realilty not by being correlated with human experience, but through the mysterious, eschatological work of the Holy Spirt in the church"61. Net so min as wat dit die prediker is wat 'n preek effektief maak, net so min vorm die Skrifverhale gelowiges in die kerk deur 'n blote navertel van die verhale. Die werk van God se Gees in die kerk se interpretasie, sakramentele lewe, prediking, gemeenskap en sending in die wêreld vorm dus 'n onmisbare deel in ' $n$ postliberale benadering tot die homiletiek ${ }^{62}$. 
5.4 Die voortsetting van die narratief in die leefwêreld van gelowiges Die sleutel tot Christenwees binne 'n kultuur-linguistiese benadering is nie bloot kennis van 'n aantal kognitief-proposisionele waarhede of 'n individuele religieuse ervaring nie, maar is die taal en praktyke van 'n Christelike gemeenskap wat as vaardighede aangeleer moet word. 'n Postliberale homiletiek fokus dus op die aanleer van hierdie vaardighede wat dan sekere idees en ervarings moontlik maak. Dit beteken die doel van prediking is die modellering in die gebruik van Christelike taal en daarmee saam die opvoeding van mense in die regte gebruik van daardie taal63.

Die taal en praktyke wat op laasgenoemde manier aangeleer word, skep geleentheid vir die kreatiewe en verbeeldingryke uitlewing daarvan in die alledaagse leefwêreld van gelowiges. Daarom speel verbeelding ' $n$ belangrike rol in ' $n$ postliberale homiletiek en bied interessante moontlikhede vir die prediker - "For postliberal preachers, imaginations's opportunity is to explore the world of the text and to note the interplay, tension, and conflict between that world and our conventional personal and social worlds" 64 .

Waar die taal en praktyke van die Christelike gemeenskap aangeleer word, vind die integrasie van drie dinge plaas: teologie, liturgie en etiek (leer, aanbidding en lewe). God se verlossende genade word 'n werklikheid en raak effektief deur die kerk se praktyke van Woord, sakrament en dissipelskap. Campbell vat die belang van die voortsetting van die Christelike narratief deur dissipelskap soos volg saam: "The 'problem' of the meaningfulness of Jesus Christ is 'solved' in the concrete worship and discipleship of the Christian community in and for the world, not by means of general anthropology or philosophy" 65 .

\section{KRITIEK TEEN DIE POSTLIBERALE TRADISIE}

Teologie as kritiese geloofsverantwoording vra ook vir kritiese refleksie oor hierdie teologiese tradisie. Die volgende is van die kritiek wat in die literatuur aangetref word:

* Wat die postliberale teologie betref, is daar volgens Placher ' $\mathrm{n}$ lewendige diskussie aan die gang ${ }^{66}$. Sake wat die meeste aandag geniet is die volgende: Eerstens is daar die vraag na waarheid. Die mees algemene punt van kritiek is dat die postliberalisme 'n vorm van relativisme is wat nie aanspraak maak op die waarheid van die Christelike geloof nie, maar slegs verslag doen van verhale wat 
binne 'n spesifieke gemeenskap vertel word. Tweedens is daar die vraag na die samehang van die narratiewe. Nuwere Bybelnavorsing het getoon dat daar verskillende, selfs konflikterende verhale, in die Skrif gevind word. Dit beteken dat die gedagte van 'n koherente narratief onder verdenking is en daarmee saam die postliberale teoloë se appèl op die Christelike gemeenskap of die Bybelse narratief. Groter terminologiese klaarheid is nodig. Derdens is daar die vraag na sektarisme. Hauerwas en Lindbeck beklemtoon 'n vorm van "sosiologiese sektarisme". Dit beteken dat Christene hulself as buitestaanders bevind tot die dominante kulturele waardes. Die probleem in die V S A en die R S A is dat die Christendom nie ' klein minderheid is nie en dus met die uitdaging sit om sosiale verantwoordelikhede as Christelike gemeenskap te aanvaar.

Soortgelyk kritiek as dié waarvan Placher melding maak, vind ons by Scuka. Ten spyte van die waardering wat hy vir Frei het, in die besonder vir die manier waarop Frei die verhouding tussen die vorm en inhoud van die Bybelse literatuur verstaan het, het hy probleme met Frei se hermeneutiese voorveronderstellings wat betref die wese van taal en narratief. Met behulp van Paul Ricoeur se weldeurdagte hermeneutiese teorie en dan in die besonder sy verstaan van die narratief, ontwikkel Scuka 'n alternatief tot die narratiewe hermeneutiek van Frei67.

Wat die postliberale hermeneutiek betref, het Van Huyssteen vrae oor die epistemologiese status van teologiese teorieë wat gebaseer is op narratiewe en metafore. Ten spyte van sy waardering vir die narratiewe paradigma as 'n essensiële genre vir die kommunikasie van die evangelie, los dit volgens hom nie heeltemal die epistemologiese probleem op in verband met die rol van rasionaliteit in kontemporêre teologie nie. 'n Narratiewe teologiese benadering wat nie aandag skenk aan die regverdiging van die kognitiewe aansprake van teologiese uitsprake nie, ignoreer die vraag na waarheid en die probleem van die vorming van rasionaliteit in teologiese refleksie. Volgens hom kan die kognitiewe aansprake van die Christelike geloof daarom nie alleen geregverdig word op grond van narratiewe vertrekpunte nie, maar is ook ander epistemiese waardes nodig soos die beskrywing van realiteit, kontekstualiteit, probleemoplossing en verduidelikende voortgang68. 
Wat die literatuur en verskillende genres van die Bybel betref, wys Tom Long dat die nie-narratiewe dele in die Bybel, deur 'n oorbeklemtoning van die narratief, onderspeel kan word en die kommunikasie van die prediking tot 'n enkele metode kan vernou. Ten spyte daarvan dat die evangelie ten diepste 'n narratief is en dat elke Skrifgedeelte in ' $n$ groter narratiewe raamwerk inpas, is die feit van die saak dat daar nie-narratiewe tekste soos didaktiese-, poëtiese- en wysheidstekste bestaan, en vir goeie redes ${ }^{69}$.

* Wat die homiletiek as sodanig betref, vra Den Dulk die vraag: Is die preek bedoel as betoog of as verhaal? Hy wys dan hoedat laasgenoemde op twee uiteenlopende tradisies berus. In die tradisie van die betoog speel die retoriek 'n sleutelrol en bestaan die preek uit 'n weldeurdagte rede wat die hoorder wil oortuig. Wat die tradisie van die verhaal betref, word gepoog om die hoorders mee te neem in ' $n$ hermeneutiese proses waar hulle ruimte kry vir eie interpretasie en ontwikkeling. Dit is duidelik dat die postliberale homiletiek se wortels in laasgenoemde gevind kan word. In aansluiting by Den Dulk is dit myns insiens nodig dat die twee benaderings mekaar moet komplementeer. Den Dulk wys dan ook hoedat die homiletiek van Miskotte en Vos pogings is om versoening tussen dié twee benaderings te bewerk ${ }^{70}$.

\section{KONKLUSIE}

Ten spyte van genoemde kritiek, sou die waarde van die postliberale teologie vir die homiletiek myns insiens in die volgende punte opgesom kon word:

* Die postliberale tradisie beklemtoon opnuut dat ons nadenke oor die homiletiek en liturgie ten diepste op sekere teologiese voorveronderstellings berus. Geen nuwe homiletiese tegniek of preekvorm kan opmaak vir 'n gebrek aan teologiese refleksie nie. In die ontwikkeling van nuwe homiletiese teorieë en praktyke is die ontwikkeling van ryker teologiese alternatiewe dan ook 'n saak van prioriteit. Dit beteken onder andere dat die doel, metode en inhoud van dié alternatiewe uitgeklaar moet word.

* Die postliberale tradisie laat die fokus val op die nou verband wat bestaan tussen die vorm, inhoud (fokus) en funksie van die Bybelse 
literatuur. Frei het in aansluiting by Barth en op grond van sy kennis van die literêre kritiek dit beklemtoon dat die vorm en funksie van 'n verhaal of diskoers net so belangrik is as die inhoud daarvan. Daar bestaan dus waardering vir die Bybel as "teks" en die performatiewe "funksie" van die teks, eerder as om dit as "bron" te beskou waaruit betekenis agter die teks ontgin kan word, soos wat met historiese kritiek die geval is.

In aansluiting by laasgenoemde plaas die postliberale tradisie 'n besondere klem op die "Bybelse narratief". Dié narratief as venster op God en sy handelinge met mense, open verbeeldingryke moontlikhede vir die prediker. Hier is dit belangrik om te begryp dat dit nie in die eerste plek gaan oor die narratief as ervaringskategorie nie, of oor die narratief se vermoë om ervaring te wek nie, maar oor die "logika" van die groter Bybelse narratief. Die klem val dus op die narratief as voertuig waardeur die identiteit Jesus van Jesus van Nasaret verbeeldingryk gekommunikeer word.

In dié verband is die hermeneutiese toerie van Paul Ricoeur, en in die besonder sy verstaan van metaforiese en narratiewe taalgebruik, 'n belangrike aanvulling tot die postliberale benadering71. Ricoeur se gedagtes oor die aard van poëtiese en religieuse diskoers met 'n simboliese dubbele intensie open kreatiewe moontlikhede, nie alleen vir menslike bestaan as sodanig nie, maar ook vir die homiletiek en liturgie ${ }^{72}$. Dit is veral die krag wat narratiewe as eksistensiële model besit om deur middel van die karakters in die verhaal (met Jesus van Nasaret as sentrale karakter) nuwe potensiaal vir die mens se bestaan aan te dui, wat sy hermeneutiese refleksie so waardevol maak.

Die postliberale teologie beklemtoon die rol van die geloofsgemeenskap. Homileties vertaal beteken dit dat die prediking en liturgie 'n belangrike rol speel in die opbou van die geloofsgemeenskap deur die aanleer van die taal en praktyke van die Christelike geloof. Die preek en liturgie help dus met die aanleer van vaardighede in die regte gebruik van dié taal, en dien terselfdertyd as geleentheid vir die inoefening van die Christelike deugde in die erediens.

Verder het 'n mens begrip vir die postliberale benadering se kritiek wat via Barth, Frei en Campbell aan die adres van die liberale teologie en in die verlengde daarvan ook aan narratiewe prediking 
gerig word. Dié kritiek moet egter met omsigtigheid hanteer word. Dit geld veral die homiletiese praktyk wat betref die vormgewing van die preek in die NG Kerk, waarmee die navorser bekend is. In empiriese navorsing oor die vormgewing van die preek het Nell tot die bevinding gekom dat daar, wat die prediking in die NG Kerk betref, maar eers redelik onlangs 'n oplewing in belangstelling ontwikkel het in narratiewe prediking en verhalende preekvorme. Dit dui moontlik op die feit dat die kognitief-proposisionele benadering al meer onder verdenking kom $^{73}$. Die kritiek wat die postliberale homiletiek dan op die ervarings-ekspressiewe benadering het, met die narratiewe prediking as uitvloeisel daarvan, sou maklik kon lei tot 'n "voortydige" negatiewe waardering van die opwindende moontlikhede van narratiewe prediking. Verder kan dit ook lei tot die huiwering om kennis te neem van en te eksperimenteer met verhalende prediking en preekvorme. Dit kan weer tot gevolg hê dat daar dan nie werklik waardering kan ontwikkel vir die alternatief van 'n kultuur-linguistiese benadering wat kenmerkend is van die postliberale teologie nie.

\section{NOTAS:}

1 Vergelyk H J Hendriks, “Makrogemeente-tendense - 1997", NGTT 39/1 en 2 (1998), 131-141.

2 Vergelyk C L Campbell, Preaching Jesus: New Directions for Homiletics in Hans Frei's Postliberal Theology, Grand Rapids 1997, xi.

3 Vergelyk onder andere die navorsing van: C W Burger, Die verhouding wetevangelie as hermeneuties homiletiese prinsipe by Hans-Joachim Iwand, DThproefskrif, Universiteit van Stellenbosch, 1983; J H Cilliers, Soos woorde van God. DTh-proefskrif, Universiteit van Stellenbosch, 1982; J H Cilliers, Die uitwysing van God op die kansel, Kaapstad 1998; J S Kellerman, Vormgewing van die prediking as kommunikasieprobleem, DTh-proefskrif,. Stellenbosch 1978. B A Müller, Die lewende Woord aan die mens van die hede, Zaandijk 1961. J C Müller, Die homilie as wyse van eietydse prediking, DD-proefskrif, Universiteit van Pretoria 1984. I A Nell, 'n Prakties-teologiese ondersoek na die vormgewing van die preek, DD-proefskrif, Universiteit van Pretoria 1996. H J C Pieterse, Skrifverstaan en prediking, Pretoria 1979; H J C Pieterse, Verwoording en prediking, Pretoria 1985; H J C Pieterse, Gemeente en prediking, Pretoria 1991; C J A Vos, Die Volheid Daarvan I en II. Homiletiek uit 'n hermeneuties-kommunikatiewe perspektief, Pretoria 1996.

4 G A Lindbeck, The Nature of Doctrine: Religion and theology in a postliberal age, Philadelphia 1984.

5 Vergelyk A E McGrath, Christian Theology: An Introduction, Oxford 1994; W C Placher, "Postliberal Theology" in: D F Ford (ed) The Modern Theologians: An Introduction to Christian Theology in the Twentieth Century, 1997, 343-342. 
$6 \quad$ Placher, $a w, 343$.

7 Placher, $a w, 343-344$.

8 Vergelyk McGrath, $a w, 109$; Placher, $a w, 344$.

9 Vergelyk McGrath, $a w, 109$; Placher, $a w, 344$.

$10 \mathrm{H}$ W Frei, The Eclipse of Biblical Narrative; A Study in Eighteenth and Nineteenth Century Hermeneutics, New Haven 1974.

11 Campbell, $a w, 44$.

12 Campbell, $a w, 45$.

13 Campbell, $a w, 51-53$.

14 Campbell, $a w, 57$.

15 Placher, $a w, 352$.

16 Placher, $a w, 344$.

$17 \quad$ Lindbeck, $a w, 16$.

18 Lindbeck, $a w, 16$.

19 Vergelyk R L Eslinger, Narrative Imagination: Preaching the Worlds That Shape Us, Philadelphia 1995, 14.

20 Die rede waarom narratief hier in die enkelvoud en nie in die meervoud gebruik word nie, hou verband met die feit dat dit vir die postliberale teoloë inderdaad oor die Bybelse (Christus-) narratief gaan. Dit sluit aan by Barth se "wêreld van die Bybel" wat voor ons open. Natuurlik impliseer dit dat die onderskeie narratiewe van die Bybel ook élkeen met respek en kreatief gelees moet word, maar dan binne dié "verhaal".

$21 \quad$ Placher, $a w, 37$.

22 Lindbeck, $a w, 18$.

23 Lindbeck, $a w, 33$.

24 Campbell, $a w, 68$.

25 Lindbeck, $a w, 34$.

26 McGrath, $a w, 110$.

27 Placher, $a w, 37$.

28 Vergelyk E Fowl \& L G Jones, Reading in Communion: Scripture and Ethics in Christian Life, Michigan 1991. Hulle maak baie van "practices of discipleship", vergelyk bloot die titel van hulle boek. Laasgenoemde is dan ook 'n goeie voorbeeld van hermeneutiek in die "Yale-gees".

29 Eslinger, $a w, 20$.

$30 \quad$ Frei, $a w, 99$.

$31 \quad$ Placher, $a w, 345$.

32 Frei, $a w, 10,13,273$.

33 Frei, $a w, 14$.

34 Vergelyk Placher, $a w, 38 \mathrm{ev;} \mathrm{Eslinger,} a w, 20-26$.

35 Vergelyk J C Holbert, Preaching the Old Testament: Proclamation and Narrative in the Hebrew Bible, Nashville 1991.

36 Eslinger, $a w, 22$.

37 R F Thieman, Revelation and theology: The gospel as narrated promise. Notre Dame 1987, 84.

38 Eslinger, $a w, 25$.

39 Thieman, $a w, 84-85$.

$40 \quad$ Eslinger, $a w, 26$. 
41 W Brueggemann, "The Social Nature of the Biblical Text for Preaching" in: A Van Seters (ed), Preaching as a Social Act: Theology and Practice, 1988, $127-$ 165.

42 S Hauerwas, "The Church as God's New Language", in: G Green (ed) Scriptural Authority and Narrative Interpretation (1987), 193.

$43 \mathrm{C}$ Rice, Interpretation and Imagination: The Preacher and Contemporary Literature, Philadelphia 1970.

44 F Craddock, As One Without Authority: Essays on Inductive Preaching, Nashville 1979.

45 E Lowry, The Homiletical Plot: The Sermon as Narrative Art Form. Atlanta, 1980; E Lowry, Doing Time in the Pulpit: The Relationship Between Narrative and Preaching, Nashville 1985.

46 Campbell, $a w, 120$.

47 Campbell, $a w, 121$.

48 Campbell, $a w, 121$.

49 Campbell, $a w, 122-123$.

50 Lindbeck, $a w, 121$.

51 Campbell, $a w, 189-199$.

52 Dit beteken dat christelike prediking ten diepste by die Evangelies begin met die opstanding en die gelykenisse wat sentraal staan. Maar dit vorm deel van die "groter verhaal" van God met die Godsvolk (Israel) en die Nuwe-testamentiese kerk en uiteindelik met die skepping en kosmos wat alles ook deel uitmaak van dié verhaal.

53 Frei, $a w, 131,136-138$; Campbell, $a w, 191-192$.

54 Campbell, $a w, 201-211$.

55 Campbell, $a w, 212-220$.

56 Campbell, $a w, 216$.

57 Campbell, $a w, 219-220$.

58 Eslinger, $a w, 27-30$.

59 Eslinger, $a w, 34$.

60 Campbell, $a w, 222$.

61 Campbell, $a w, 61$.

62 Eslinger, $a w, 35$.

63 Campbell, $a w, 231-241$.

64 Eslinger, $a w, 99$.

65 Campbell, $a w, 62$.

66 Placher, $a w, 350-352$.

67 R F Scuka, The Retrieval of Biblical Narrative: A Constructive Alternative to the Narrative Hermeneutics of Hans Frei, UMI Dissertation Services, 1987.

68 W van Huyssteen, "Narrative theology: An adequate paradigm for theological reflection?" Hervormde Teologiese Studies 45 (1989), 767-777.

69 T G Long, The Witness of Preaching, Kentucky 1989, 40-41.

70 M den Dulk, "Betoog of verhaal: Een verwarrende dilemma", Postille 42 (1996), 7-30.

71 Vergelyk P Ricoeur, The rule of Metaphor. Multi-disciplinary studies of the creation of meaning in language, London 1978; P Ricoeur, "Naming God", Union Seminary Quarterly Review, 34/4 (1979), 15-27. 
72 Vergelyk Vos, $a w, 23-47$, se ontginning van laasgenoemde vir die homiletiek.

73 Vergelyk Nell, $a w, 331$. 